\title{
HUBUNGAN ANTARA FASILITAS BENGKEL BANGUNAN DAN MINAT BELAJAR SISWA DENGAN HASIL BELAJAR PRAKTEK BATU PADA SISWA KELAS XI PROGRAM KEAHLIAN KONSTRUKSI BATU DAN BETON SMK NEGERI 2 PEMATANGSIANTAR
}

\author{
Dimpu Nababan ${ }^{1)}$ dan Iskandar Tambunan ${ }^{2)}$
}

\section{Iskandartambunan23@gmail.com}

\begin{abstract}
Abstrak
Penelitian ini bertujuan untuk mengetahui Hubungan Antara Fasilitas Bengkel Bangunan dan Minat Belajar Siswa Dengan Hasil Belajar Praktek Batu Pada Siswa Kelas XI Program Keahlian Konstruksi Batu dan Beton SMK Negeri 2 Pematangsiantar Tahun Ajaran 2012/2013 dengan jumlah responden 31 orang.

Data penelitian variabel fasilitas bengkel bangunan $\left(\mathrm{X}_{1}\right)$ dan minat belajar $\left(\mathrm{X}_{2}\right)$ dijaring dengan angket. Hasil belajar praktek batu (Y) dijaring menggunakan tes.

Berdasarkan uji coba instrumen didapat hasil : (1) variabel fasilitas bengkel bangunan $\left(\mathrm{X}_{1}\right) 23$ valid, reabilitas sangat tinggi sebesar 0,847 pada taraf signifikansi 5\%. (2) variabel minat belajar $\left(\mathrm{X}_{2}\right) 24$ valid, reabilitas sangat tinggi sebesar 0,768 pada taraf signifikansi 5\%. (3) variabel hasil belajar praktek batu (Y) 26 soal yang valid, reliabilitas sangat tinggi sebesar 0,742 pada taraf signifikansi 5\%. Indeks kesukaran tes hasil belajar praktek batu yaitu 20 soal kategori sedang dan 6 soal kategori mudah. Daya pembeda butir soal hasil belajar praktek batu terdapat 5 kategori jelek, 14 soal kategori cukup, dan 7 kategori baik.

Uji normalitas dengan chi kuadrat masing-masing variabel penelitian didapat hasil sebagai berikut : (1) variabel fasilitas bengkel bangunan $\left(X_{1}\right)$ yaitu $\chi^{2}$ hitung $=10,245<\chi^{2}$ tabel $=11,070$, (2) minat belajar $\left(\mathrm{X}_{2}\right)$ yaitu $\chi^{2}$ hitung $=6,825<\chi_{\text {tabel }}^{2}=11,070$, (3) variabel hasil belajar praktek batu (Y) yaitu $\chi^{2}$ hitung $=8,818<\chi^{2}$ tabel $=11,070$, dengan masing-masing berdistribusi normal pada taraf signfikansi $5 \%$.

Hasil uji masing-masing variabel penelitian didapat hasil (1) persamaan regresi sederhana $\mathrm{Y}$ atas $\mathrm{X}_{1}$ yaitu $\hat{\mathrm{Y}}=17,448-0,025 \mathrm{X}_{1}$, uji coba kelinieran persamaan regresi $\mathrm{Y}$ atas $\mathrm{X}_{1}$ yaitu $\mathrm{F}_{\text {hitung }}=4,96>\mathrm{F}_{\text {tabel }}=4,18$ mempunyai konstribusi yang linier dan berarti pada taraf signifikansi $5 \%$. (2) persamaan regresi sederhana $\mathrm{Y}$ atas $\mathrm{X}_{2}$ yaitu $\hat{\mathrm{Y}}=20,239-0,062 \mathrm{X}_{2}$, uji coba kelinieran persamaan regresi $\mathrm{Y}$ atas $\mathrm{X}_{2}$ yaitu $\mathrm{F}_{\text {hitung }}=4,346>\mathrm{F}_{\text {tabel }}=4,18$ mempunyai konstribusi yang linier dan berarti pada taraf signifikansi $5 \%$.

Hasil analisis korelasi antar variabel didapat hasil : (1) variabel fasilitas bengkel bangunan $\left(\mathrm{X}_{1}\right)$ dengan hasil belajar praktek batu $(\mathrm{Y})$ yaitu $\mathrm{r}_{\text {hitung }}=0,467>\mathrm{r}_{\text {tabel }}=0,355$ menunjukkan korelasi positif dan berarti pada taraf signifikansi 5\%. (2) minat belajar $\left(\mathrm{X}_{2}\right)$ dengan hasil belajar praktek batu $(\mathrm{Y})$ yaitu $\mathrm{r}_{\text {hitung }}=0,389>\mathrm{r}_{\text {tabel }}=0,355$ menunjukkan korelasi positif dan berarti pada taraf signifikansi $5 \%$.

Korelasi ganda antara $\mathrm{X}_{1}$ dan $\mathrm{X}_{2}$ terhadap $\mathrm{Y}$ menunjukkan korelasi yang positif dan berarti dengan $r=0,553$ dan $R^{2}=0,306$ yang berarti $30,60 \%$ mata pelajaran praktek batu dapat dijelaskan secara bersama-sama oleh fasilitas bengkel bangunan dan minat belajar dan sisanya dijelaskan oleh variabel lainnya.
\end{abstract}

\section{Kata-kata Kunci: Fasilitas Bengkel Bangunan, Minat Belajar, Hasil Belajar Praktek Batu}

\section{PENDAHULUAN}

Sekolah Menengah Kejuruan (SMK)

sebagai bagian intergal dari sistem pendidikan di Indonesia memegang peranan penting dalam meningkatkan sumber daya

1) Dimpu Nababan, alumni Pendidikan Teknik Bangunan FT Unimed

2) Drs. Iskandar Tambunan, M.Pd. Dosen Jurusan Pendidikan Teknik Bangunan FT Unimed 
manusia, khususnya dalam mempersiapkan tenaga kerja menengah. Hal ini sesuai dengan tujuan pendidikan yang tercantum dalam UU RI No. 20/2003 tentang sisdiknas, dikatakan : "pendidikan kejuruan merupakan pendidikan menengah yang mempersiapkan peserta didik terutama untuk bekerja dalam bidang tertentu."

Pendidikan merupakan suatu pembekalan bagi setiap individu berupa pembentukan sikap, pengetahuan dan keterampilan kerja. Dalam arti kata, pendidikan menghasikan sumber daya manusia (SDM) yang tangguh, mampu dan siap bekerja sehingga dapat mengisi semua jenis ataupun tingkat lapangan pekerjaan sesuai dengan pendidikan yang diraihnya.

Untuk mencapai tujuan pendidikan nasional itu, sekolah menengah kejuruan (SMK) sebagai suatu lembaga pendidikan yang mengelola pendidikan dalam bidang teknologi dan kejuruan juga mempunyai tujuan secara umum, seperti dimuat dalam Garis-garis Besar Program Pendidikan dan Pelatihan (GBPP) edisi 2004, menyatakan bahwa tujuan SMK adalah:

1) Mengutamakan persiapan siswa untuk memenuhi lapangan kerja serta mengembangkan sikap professional. 2) Menyiapkan siswa agar mampu merintis karier, mampu berkompetisi dan mampu mengembangkan diri.

3)

Menyiapkan tenaga kerja tingkat menengah untuk mengisi kebutuhan dunia kerja saat ini saat ini dan masa yang akan datang. 4) Menyiapkan tamatan agar mampu menjadi warga negara yang produktif, adaptif, dan kreatif.

SMK terdiri dari beberapa program keahlian yang mempunyai tujuan khusus. Salah satu program keahlian itu adalah program keahlian teknik bangunan yang mempunyai tujuan khusus untuk mendidik siswa agar:
1) Mampu memasuki lapangan kerja serta mengembangkan sikap profesional dalam lingkup keahlian teknik bangunan.

2) Mampu merintis karier, mampu berkompetensi dan mampu mengembangkan diri dalam lingkup keahlian teknik bangunan. 3) Menjadi tenaga kerja tingkat menengah untuk mengisi kebutuhan dunia kerja saat ini dan akan datang dalam lingkup keahlian teknik bangunan. 4) Menjadi warga Negara yang produktif, adaktif, dan kreatif

Sesuai dengan tujuan pendidikan SMK yang dimuat dalam GBPP SMK edisi 2004, dapat diambil kesimpulan bahwa lulusan SMK disiapkan sebagai tenaga kerja yang dititik beratkan pada keterampilan kerja (skill). Oleh karena itu lembaga tersebut (SMK) wajib memilki bengkel (workshop) sebagai tempat atau lokasi praktik siswa. Di dalam bengkel inilah siswa dilatih dan dibekali dengan kemampuan aplikasi atau praktik yang materinya disesuaikan dengan kurikulum yang berlaku sebagai lembaga pendidikan tersebut khususnya SMK.

Sejalan dengan tujuan SMK itu, Purtowisastro (1986:25) menyatakan bahwa: "Penggunaan alat-alat dalam proses belajar mengajar bertujuan meningkatkan motivasi siswa untuk lebih berhasil". Semakin tinggi motivasi belajar maka akan semakin tinggi pula hasil belajar siswa, pendapat ini dibuktikan dengan hasil penelitian lain yang menyebutkan terdapat hubungan positif dan berarti antara motivasi belajar dengan hasil belajar. Pendapat di atas menjelaskan bahwa fasilitas bengkel bangunan dapat memberi motivasi kepada siswa untuk menjalankan praktik dengan semangat belajar yang tinggi, dimana motivasi ini kemudian akan meningkatkan hasil belajar siswa tersebut. Hal ini juga dapat dilakukan dengan penambahan fasilitas praktik di bengkel bangunan yang diharapkan dengan menghasilkan 
Hubungan Antara Fasilitas Bengkel Bangunan Dan Minat Belajar Siswa Dengan Hasil Belajar Praktek Batu Pada Siswa Kelas Xi Program Keahlian Konstruksi Batu Dan Beton Smk Negeri 2 Pematangsiantar

keterampilan (skill) yang lebih tinggi bagi siswa yang melakukan praktek dan meningkatkan minat belajar siswa yang berkaitan dengan fasilitas bengkel bangunan dan tentunya tujuan akhirnya adalah peningkatan hasil belajar siswa khususnya pada praktek batu.

Keaktifan siswa dalam mengikuti proses belajar merupakan ciri khas siswa yang memiliki minat belajar. Apabila seseorang menaruh minat pada sesuatu maka minatnya akan menjadi motif kuat pada dirinya berhubungan secara aktif dengan yang membuatnya menjadi tertarik. Sama halnya dengan pelajaran, apabila seseorang menaruh minat pada pelajaran tertentu maka dia akan senang dan berusaha mempelajarinya. Pelajaran akan lancar bila ada minat, anak malas dan tidak belajar atau gagal disebabkan oleh karena tidak ada minat. Jadi dapat disimpukan bahwa minat adalah motif yang kuat bagi siswa untuk mendapatkan hasil belajar yang baik khususnya pratek batu. Dalam menumbuhkan minat belajar bukanlah suatu hal yang mudah oleh karena beberapa faktor turut mempengaruhi dan setelah tumbuh minat, bagaimana usaha agar minat dapat dikembangkan dan dipertahankan, merupakan hal yang perlu.

Berdasarkan penjelasan di atas, ada 3 (tiga) hal yang saling berhubungan dan selanjutnya akan dibahas pada bab selanjutnya yaitu: Minat Belajar, Fasilitas Bengkel Bangunan, dan Hasil Belajar Praktek Batu.

Memperlihatkan akan pentingnya fasilitas bengkel bangunan dan minat belajar, maka penulis tertarik untuk melakukan penelitian dengan judul :

"Hubungan Antara Fasilitas Bengkel Bangunan dan Minat Belajar Siswa dengan Hasil Belajar Praktek Batu Pada Siswa Kelas XI Program Keahlian Konstruksi Batu Dan Beton SMK Negeri 2 Pematangsiantar Tahun Ajaran 2012/2013".
Berdasarkan latar belakang yang telah dikemukakan di atas, maka masalah penelitian ini diidentifikasikan sebagai berikut:

1. Bagaimana kondisi Fasilitas Bengkel Bangunan di SMK Negeri 2 Pematangsiantar?

2. Faktor apa sajakah yang mempengaruhi minat belajar siswa SMK Negeri 2 Pematangsiantar?

3. Faktor apa sajakah yang mempengaruhi hasil belajar SMK Negeri 2 Pematangsiantar?

4. Bagaimana hasil belajar praktek batu siswa SMK Negeri 2 Pematangsiantar?

5. Apakah ada hubungan fasilitas bengkel bangunan dengan hasil belajar praktek batu?

6. Apakah ada hubungan minat belajar dengan hasil belajar praktek batu?

7. Apakah ada hubungan fasilitas bengkel bangunan dan minat belajar terhadap hasil belajar praktek batu?

8. Apakah siswa kelas XI Program Keahlian Konstruksi Batu dan Beton di SMK Negeri 2 Pematangsiantar Tahun Ajaran 2012/2013 mempunyai minat belajar yang tinggi dalam melakukan praktek di bengkel?

Dengan keterbatasan peneliti baik dari segi waktu maupun dana dan untuk menghindari penafsiran yang berbeda-beda, maka masalah dalam penelitian ini dibatasi pada hubungan fasilitas bengkel bangunan dan minat belajar dengan hasil belajar praktek batu pada siswa kelas XI Program Keahlian Konstruksi Batu dan Beton SMK Negeri 2 Pematangsiantar Tahun Ajaran 2012/2013.

Berdasarkan identifikasi dan batasan masalah di atas maka perumusan masalah dalam penelitian ini adalah sebagai berikut:

1. Apakah terdapat hubungan yang positif dan signifikan antara fasilitas bengkel

1) Dimpu Nababan, alumni Pendidikan Teknik Bangunan FT Unimed

2) Drs. Iskandar Tambunan, M.Pd. Dosen Jurusan Pendidikan Teknik Bangunan FT Unimed 
Hubungan Antara Fasilitas Bengkel Bangunan Dan Minat Belajar Siswa Dengan Hasil Belajar Praktek Batu Pada Siswa Kelas Xi Program Keahlian Konstruksi Batu Dan Beton Smk Negeri 2 Pematangsiantar

bangunan dan hasil belajar praktek batu?

2. Apakah terdapat hubungan yang positif dan signifikan minat antara belajar dan hasil belajar praktek batu?

3. Apakah terdapat hubungan yang positif dan signifikan antara fasilitas bengkel bangunan dan minat belajar dengan hasil belajar praktek batu?

Sesuai dengan batasan masalah di atas maka yang menjadi tujuan dari penelitian ini adalah:

1. Untuk mengetahui hubungan fasilitas bengkel bangunan siswa kelas XI Program Keahlian Konstruksi Batu dan Beton di SMK Negeri 2 Pematangsiantar Tahun Ajaran 2012/2013.

2. Untuk mengetahui hubungan minat belajar siswa kelas XI Program Keahlian Konstruksi Batu dan Beton di SMK Negeri 2 Pematangsiantar Tahun Ajaran 2012/2013.

3. Untuk mengetahui hubungan antara fasilitas bengkel bangunan dan minat belajar dengan hasil belajar praktek batu pada siswa kelas XI Program Keahlian Konstruksi Batu dan Beton SMK Negeri 2 Pematangsiantar Tahun Ajaran 2012/2013.

Hasil peneletian ini diharapkan memberikan manfaat sebagai berikut :

1. Untuk memberikan informasi tentang hubungan fasilitas bengkel bangunan dan minat belajar dengan hasil belajar praktek batu pada siswa kelas XI Program Keahlian Konstruksi Batu dan Beton SMK Negeri 2 Pematangsiantar Tahun Ajaran 2012/2013.

2. Sebagai bahan masukan bagi pengelola lembaga pendidikan khususnya bagi guru SMK Program Keahlian Konstruksi Batu dan Beton dalam usah meningkatkan mutu fasilitas praktek umumnya pada program keahlian dan khususnya pada praktek batu.
3. Sebagai bahan masukan bagi jurusan pendidikan teknik bangunan Universitas Negeri Medan, selaku penghasil guru teknik khususnya jurusan pendidikan teknik bangunan.

4. Sebagai masukan bagi pengembangan ilmu pengetahuan dalam dalam bidang pendidikan kejuruan.

5. Sebagai referensi bagi mahasiswa yang akan melakukan penelitian lebih lanjut

6. Hasil penelitian ini dapat digunakan oleh berbagai pihak sebagai bahan informasi untuk pengembangan ilmu dalam teknologi dalam bidang pendidikan.

Menurut Suryosubroto (2002:290) fasilitas merupakan media pembelajaran yang fungsi utamanya sebagai alat bantu untuk melakukan kegiatan belajar mengajar. Dari penjelasan di atas dapat diartikan bahwa fasilitas merupakan segala kebutuhan yang diperlukan untuk menyelesaikan pekerjaan.

Dalam artikel Arianto (2008 : tanpa halaman) Zakiah Daradjat menyatakan fasilitas adalah segala sesuatu yang dapat mempermudah upaya dan memperlancar kerja dalam rangka mencapai suatu tujuan. Sedangkan menurut Suryo Subroto (2008 : 36), fasilitas adalah segala sesuatu yang dapat memudahkan dan memperlancar pelaksanaan suatu usaha dapat berupa benda-benda maupun uang. Lebih luas lagi tentang pengertian fasilitas Suhaisimi Arikonto (2008 : 72) berpendapat, fasilitas dapat diartikan sebagai segala sesuatu yang dapat memudahkan dan memperlancar pelaksanaan segala sesuatu usaha.

Fasilitas menurut Sanjaya (2006:53) menyatakan "fasilitas adalah segala sesuatu yang mendukung secara langsung terhadap kelancaran proses pekerjaan. Sejalan dengan itu, dalam kamus besar bahasa Indonesia (2001:314) "Fasilitas berarti sarana untuk melancarkan pelaksanaan fungsi; kemudahan". 
Selanjutnya kata bengkel berasal dari bahasa Inggris yaitu "Workshop" atau dapat diartikan ruang kerja (Jhon M. Echols, 1993:653). Sejalan dengan itu dalam kamus besar bahasa Indonesia (2001:133) "bengkel berarti tempat tukang bekerja". Kemudian kata bangunan berasal dari bahasa Inggris yaitu "building"yang artinya bangunan.

Dengan demikian, dari pengertian di atas dapat disimpulkan bahwa fasilitas bengkel bangunan adalah faktor pendukung suatu kegiatan belajar (dengan bantuan alatalat pendukung) praktek bangunan di bengkel (ruang kerja). Kegiatan tersebut harus bejalan dengan langkah-langkah tertentu guna mendapatkan hasil kerja/praktek yang maksimal. Dalam hal ini kegiatan praktek yang dimaksud adalah yang menyangkut dengan praktek batu.

Dalam Ensiklopedi Pendidikan Minat adalah kesediaan jiwa yang sifatnya aktif untuk sesuatu dari luar. Setiap pelajaran harus dapat menarik minat siswa. Hilgrad (dalam Slameto, 2003:57) memberi rumusan tentang minat adalah sebagai berikut:'Interest persisting terdency to pay attention to end enjoy some activity or content". Dimana minat adalah kecenderungan yang tetap untuk memperhatikan dan mengenang beberapa kegiatan.

Menurut Slameto (2003:180) minat adalah suatu ras lebih suka dan rasa ketertarikan pada suatu hal atau aktivitas, tanpa ada yang menyuruh. Minat pada dasarnya adalah penerimaan akan suatu hubungan antara diri sendiri dengan sesuatu diluar diri. Minat besar pengaruhnya terhadap belajar, karena bila pelajaran yang dipelajari tidak sesuai dengan minat siswa, maka hasilnya tidak memuaskan.

Imansyah Ali Pandie menyatakan bahwa untuk memperoleh hasil pengajaran yang sebaik-baiknya dalam proses pembelajaran guru harus selalu berusaha untuk membangkitkan minat para siswa, sehingga seluruh perhatian mereka tertuju dan terpusat pada bahan pelajaran yang sesudah diajarkan.

Sementara itu menurut Sadirman A.M (1992:94) ada beberapa cara untuk membangkitkan minat belajar, yaitu: (1) membangkitkan adanya suatu kebutuhan, (2) menghubungkan dengan persoalan pengalaman yang lampau, (3) memberi kesempatan untuk mendapatkan hasil yang baik, dan (4) menggunakan berbagai macam bentuk mengajar.

Jersild dan tash dalam Nurkancana (1986:229) menekankan bahwa minat menyangkut aktivitas yang dipilih secara bebas oleh individu. Minat atau interest menyangkut gejala proses yang berkaitan dengan objek atau aktivitas yang menstimulir perasaan senang individu.

Minat yang timbul dari kebutuhan anak, akan merupakan faktor pendorong bagi anak dalam melaksanakan usahanya. Jadi, dapat dilihat bahwa minat sangat penting dalam pendidikan, sebab merupakan sumber usaha. Anak-anak tidak perlu mendapat dorongan dari luar apabila pekerjaanya yang dilakukannya cukup menaruh minatnya.

Dari beberapa uaraian diatas, minat belajar adalah rasa ketertatikan dan rasa suka dalam perubahan sesuatu akan suatu hubungan antara diri sendiri dengan sesuatu di luar diri dengan rasa senang

Secara sederhana Anthony Robbins dalam Trianto (2009:15) mendefenisikan belajar sebagai proses menciptakan hubungan antara sesuatu (pengetahuan) yang sudah dipahami dan sesuatu (pengetahuan) yang baru. Makna belajar dalam hal ini, bukan berangkat dari sesuatu yang benar-benar belum diketahui, tetapi merupakan keterkaitan dari dua pengetahuan yang sudah ada dengan pengetahuan yang baru.

Menurut Sagala (2003:11) belajar merupakan komponen ilmu pendidikan yang berkenaan dengan tujuan dan bahan 
acuan interaksi, baik yang bersifat eksplisit maupun implicit (tersembunyi). Sedangkan Slavin dalam Trianto (2009:16) mendefinisikan belajar secara lebih lengkap, belajar secara umum diartikan sebagai perubahan pada individu yang terjadi melalui pengalaman, dan bukan karena pertumbuhan atau perkembangan tubuhnya atau karakteristik seseorang sejak lahir. Manusia banyak belajar mulai dari lahir dan bahkan ada yang berpendapat sebelum lahir.

Hasil belajar yang dimaksud dalam penelitian ini adalah hasil belajar kompetensi kejuruan yaitu suatu penilaian dari hasil usaha yang dicapai siswa dari suatu kegiatan praktek kerja batu dalam pasangan batu bata dan penggunaan alat praktek yang dilakukan dalam waktu tertentu yang dinaytakan dalam bentuk angka.

Dalam kegiatan praktek batu dilakukan dalam dua kali pertemuan, pertemuan pertama (pekerjaan pembersihan lapangan, dan pekerjaan bowplank). Pertemuan kedua (pekerjaan pemasangan bata).

Fasilitas adalah segala sesuatu yang memudahkan dalam suatu kegiatan ataupun pelajaran. Oleh karena itu, dengan adanya fasilitas yang memadai (fasilitas bengkel bangunan) tentunya akan mempengaruhi siswa dalam proses belajar. Hal ini disebabkan semakin memadainya fasilitas bengkel bangunan maka minat siswa dalam melakukan praktek akan semakin tinggi.

Perhatian yang penuh terhadap materi pelajaran yang sedang dipelajari sangat dituntut dari siswa didalam kegiatan belajar mengajar sebab dengan adanya perhatian maka segala upaya akan dilakukan untuk memperoleh hasil yang lebih baik. Salah satu yang mempengaruhi timbulnya perhatian adalah minat belajar. Ketika seseorang meminati akan sesuatu hal maka dia akan menggeluti dan berusaha mendapatkannya.
Fasilitas bengkel bangunan mempunyai hubungan yang erat dengan hasil belajar praktek batu. Hal ini disebabkan karena semakin memadainya fasilitas bengkel bangunan maka minat siswa akan semakin tinggi dalam melakukan praktek atau kegiatan belajar. Timbulnya motivasi siswa dalam melakukan praktek atau belajar tentu akan meningkatkan hasil belajar siswa tersebut.

Demikian juga dengan minat belajar, semakin tinggi minat belajar siswa maka akan semakin tinggi pula hasil belajar yang dicapai. Ketika seseorang berminat akan sesuatu hal maka dia akan berusaha mendapatkan atau menggelutinya. Seseorang yang berminat dalam belajar tentunya tentu akan lebih giat dan menekuni pelajarannya, ia akan cenderung memikirkan pelajarannya dan berusaha untuk dapat menguasai pelajaran tersebut dengan baik.

Hipotesis diartikan sebagai suatu jawaban yang bersifat sementara terhadap permasalahan penelitian (Arikunto, 1990:69). Adapun yang menjadi hipotesis dalam penelitian ini adalah sebagai berikut:

1. Terdapat hubungan yang positif dan berarti antara Fasilitas Bengkel Bangunan dengan Hasil Belajar Praktek Batu pada siswa kelas XI Program Keahlian Konstruksi Batu dan Beton SMK Negeri 2 Pematangsiantar Tahun Ajaran 2012/2013.

2. Terdapat hubungan yang positif dan berarti antara Minat Belajar dengan Hasil Belajar Praktek Batu pada siswa kelas XI Program Keahlian Konstruksi Batu dan Beton SMK Negeri 2 Pematangsiantar Tahun Ajaran 2012/2013.

3. Terdapat hubungan yang positif dan berarti antara Fasilitas Bengkel Bangunan dan Minat Belajar dengan Hasil Belajar Praktek Batu pada siswa kelas XI Program Keahlian Konstruksi Batu dan Beton SMK Negeri 2

1) Dimpu Nababan, alumni Pendidikan Teknik Bangunan FT Unimed

2) Drs. Iskandar Tambunan, M.Pd. Dosen Jurusan Pendidikan Teknik Bangunan FT Unimed 
Hubungan Antara Fasilitas Bengkel Bangunan Dan Minat Belajar Siswa Dengan Hasil Belajar Praktek Batu Pada Siswa Kelas Xi Program Keahlian Konstruksi Batu Dan Beton Smk Negeri 2 Pematangsiantar
Pematangsiantar
Tahun
Ajaran
2012/2013.

\section{METODE}

Penelitian ini dilakukan pada siswa kelas XI Program Keahlian Konstruksi Batu Beton SMK Negeri 2 Pematangsiantar, selanjutnya penelitian dilaksanakan pada bulan Juni 2012 sampai dengan Agustus 2012.

Jumlah seluruh populasi kelas $\mathrm{X}$ Jurusan Teknik Bangunan SMK Negeri 2 Pematangsiantar TA 2011/2012 adalah 32 orang

Sampel penelitian adalah sebanyak 31 orang siswa kelas $\mathrm{X}$ Jurusan Teknik Gambar Bangunan SMK Negeri 2 Pematangsiantar TA 2011/2012.

Metode deskriftif korelasional yakni teknik pengumpulan data untuk mendapatkan gambaran.

Variable bebas:

- Fasilitas Bengkel Bangunan $\left(\mathrm{X}_{1}\right)$

- Minat Belajar $\left(\mathrm{X}_{2}\right)$

Variabel Terikat:

- Praktek Batu (Y)

1. Fasilitas Bengkel Bangunan (X1) dan Minat Belajar (X2) dijaring dengan menggunakan angket.

2. Hasil belajar Praktek Batu (Y) dijaring dengan menggunakan tes dan diperoleh melalui penguasaan materi pelajaran yang diambil melalui instrumen penelititian

Instrumen Fasilitas Bengkel

Bangunan (X1)

1. Instrumen Minat Belajar (X2)

2. Instrumen Hasil Belajar Praktek Batu

(Y)

Instrumen Fasilitas Bengkel

Bangunan (X1) dan Minat Belajar (X2)

1. Uji Validitas Angket

2. Uji Reabilitas Angket

$$
r_{x y}=\frac{(N \cdot \Sigma X Y)-(\Sigma X)(\Sigma Y)}{\sqrt{\left\{N \Sigma X^{2}-(\Sigma X)^{2}\right\}\left\{N \Sigma Y^{2}-(\Sigma Y)^{2}\right\}}}
$$

$$
r_{11}=\left(\frac{K}{K-1}\right)\left(1-\frac{\Sigma \sigma_{t}^{2}}{\sigma_{t}}\right)
$$

Instrumen Hasil Belajar Praktek Batu (Y)

1. Uji Validitas Tes

$$
\gamma_{p b i}=\frac{M_{p}-M_{t}}{S_{t}} \sqrt{\frac{p}{q}}
$$

2. Uji Reabilitas Tes

$$
\text { 3. } \begin{aligned}
r_{11} & =\left(\frac{n}{n-1}\right)\left(\frac{S^{2}-\Sigma p q}{S^{2}}\right) \\
P & =\frac{B}{J S}
\end{aligned}
$$

4. Uji Daya Pembeda

$$
D=\frac{B A}{J A}-\frac{B B}{J B}
$$

1) Dimpu Nababan, alumni Pendidikan Teknik Bangunan FT Unimed

2) Drs. Iskandar Tambunan, M.Pd. Dosen Jurusan Pendidikan Teknik Bangunan FT Unimed 
Hubungan Antara Fasilitas Bengkel Bangunan Dan Minat Belajar Siswa Dengan Hasil Belajar Praktek Batu Pada Siswa Kelas Xi Program Keahlian Konstruksi Batu Dan Beton Smk Negeri 2 Pematangsiantar

1. Deskripsi Data Penelitian $M=\frac{\Sigma X_{i}}{N} \quad$ dan $S D=\frac{1}{N} \sqrt{(N)-(\Sigma X)^{2}}$

2. Uji Kecendurangan

$$
\begin{aligned}
M i & =\frac{\text { skortertinggi }+ \text { skorterendah }}{2} \\
S D i & =\frac{\text { skortertinggi }- \text { skorterendah }}{6}
\end{aligned}
$$

3. Uji Persyaratan Analisis

a. Uji Normalitas

$$
\chi^{2}=\sum \frac{(f o-f h)^{2}}{f h}
$$

b. Uji Linieritas

$$
\begin{aligned}
& Y=a+b x 1 \\
& Y=a+b x 2
\end{aligned}
$$

1. Hipotesis Pertama dan Hipotesis Kedua

$$
r_{x y}=\frac{(N \cdot \Sigma X Y)-(\Sigma X)(\Sigma Y)}{\sqrt{\left\{N \Sigma X^{2}-(\Sigma X)^{2}\right\}\left(N \Sigma Y^{2}-(\Sigma Y)^{2}\right\}}}
$$

2. Hipotesis Ketiga

$Y=a_{0}+a_{1} X_{1}+a_{2} X_{2}$

1. Uji Korelasi Sederhana

$$
r_{x y}=\frac{(N \cdot \Sigma X Y)-(\Sigma X)(\Sigma Y)}{\sqrt{\left\{N \Sigma X^{2}-(\Sigma X)^{2}\right)\left(N \Sigma Y^{2}-(\Sigma Y)^{2}\right\}}}
$$

2. Uji Korelasi Ganda dan Uji Koefisien Ganda

$$
\begin{aligned}
& R^{2}=\frac{J K_{r e g}}{\Sigma Y^{2}} \\
& D=\frac{B A}{J A}-\frac{B B}{J B} \\
& F=\frac{R^{2} / K}{\left(1-r_{y 2}^{2}\right)(n-k-1)}
\end{aligned}
$$

Fasilitas Bengkel Bangunan

\begin{tabular}{|cccc|}
\hline Rentangan & F. Absolut & F. Relatif & Kategori \\
\hline $\mathbf{7 4 , 7 5}$ s/d keatas & 0 & $0 \%$ & Tinggi \\
\hline $\mathbf{5 7 , 5}$ s/d 74,75 & 12 & $38,71 \%$ & Cukup \\
\hline $\mathbf{4 0 , 2 5}$ s/d 57,5 & 19 & $61,29 \%$ & Kurang \\
\hline $\mathbf{4 0 , 2 5}$ s/d ke bawah & 0 & $0 \%$ & Rendah \\
\hline Jumlah & 31 & $100 \%$ & \\
\hline
\end{tabular}

\section{HASIL PENELITIAN}

1. Fasilitas Bengkel Bangunan $\left(\mathrm{X}_{1}\right)$

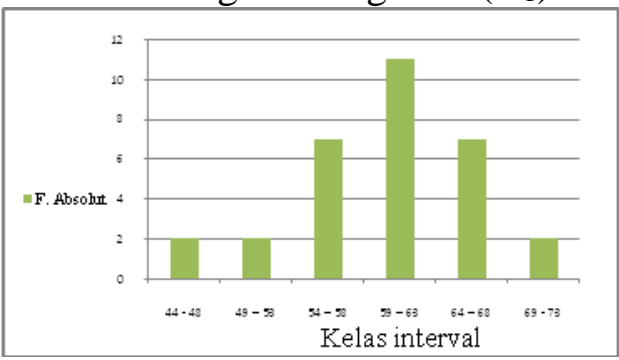

2. Minat Belajar

3. Hasil Belajar Praktek Batu (Y)
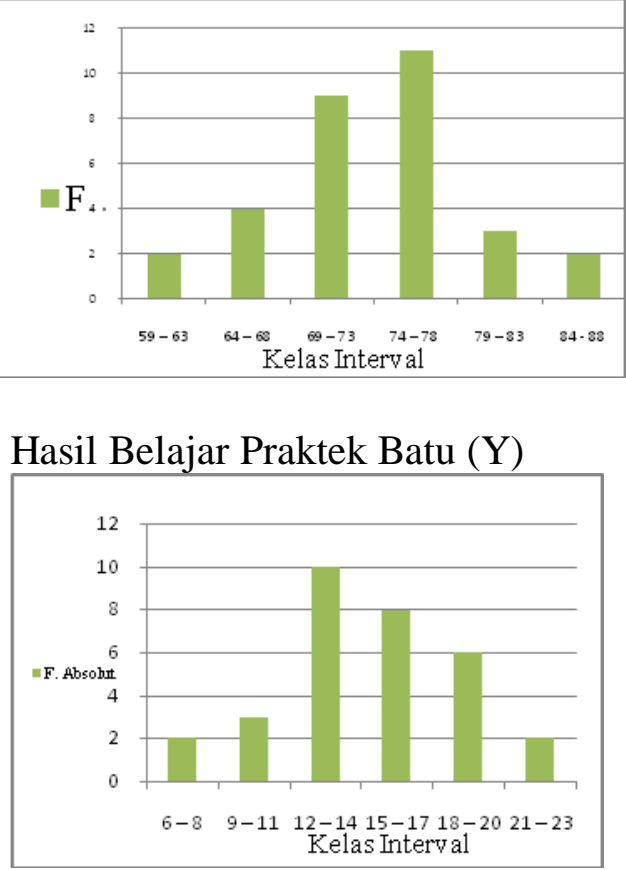

3. Uji Korelasi Parsial

$$
r_{y 12}=\frac{r_{y 1}-r_{y 2} r_{12}}{\sqrt{\left(1-r_{y 2}^{2}\right)\left(1-r_{12}^{2}\right)}}
$$

1) Dimpu Nababan, alumni Pendidikan Teknik Bangunan FT Unimed

2) Drs. Iskandar Tambunan, M.Pd. Dosen Jurusan Pendidikan Teknik Bangunan FT Unimed 
Hubungan Antara Fasilitas Bengkel Bangunan Dan Minat Belajar Siswa Dengan Hasil Belajar Praktek Batu Pada Siswa Kelas Xi Program Keahlian Konstruksi Batu Dan Beton Smk Negeri 2 Pematangsiantar

Disiplin Belajar

\begin{tabular}{|cccl|}
\hline Rentangan & $\begin{array}{c}\text { F. } \\
\text { Absolut }\end{array}$ & F. Relatif & Kategori \\
\hline $\mathbf{7 8}$ s/d keatas & 0 & $0 \%$ & Tinggi \\
\hline $\mathbf{6 0}$ s/d 78 & 20 & $64,52 \%$ & Cukup \\
\hline $\mathbf{4 2}$ s/d 60 & 11 & $35,48 \%$ & Kurang \\
\hline $\mathbf{4 2}$ s/d ke bawah & 0 & $0 \%$ & Rendah \\
\hline Jumlah & 31 & $100 \%$ & \\
\hline
\end{tabular}

Hasil Belajar Pengetahuan Dasar Teknik Bangunan

\begin{tabular}{|cccc|}
\hline Rentangan & F. Absolut & F. Relatif & Kategori \\
\hline $\mathbf{1 9 , 4 9 9}$ s/d keatas & 4 & $12,90 \%$ & Tinggi \\
\hline $\mathbf{1 3}$ s/d 19,499 & 22 & $70,97 \%$ & Cukup \\
\hline $\mathbf{6 , 5 0}$ s/d 13 & 5 & $16,13 \%$ & Kurang \\
\hline $\mathbf{6 , 5 0}$ s/d ke bawah & 0 & $0 \%$ & Rendah \\
\hline Jumlah & 31 & $100 \%$ & \\
\hline
\end{tabular}

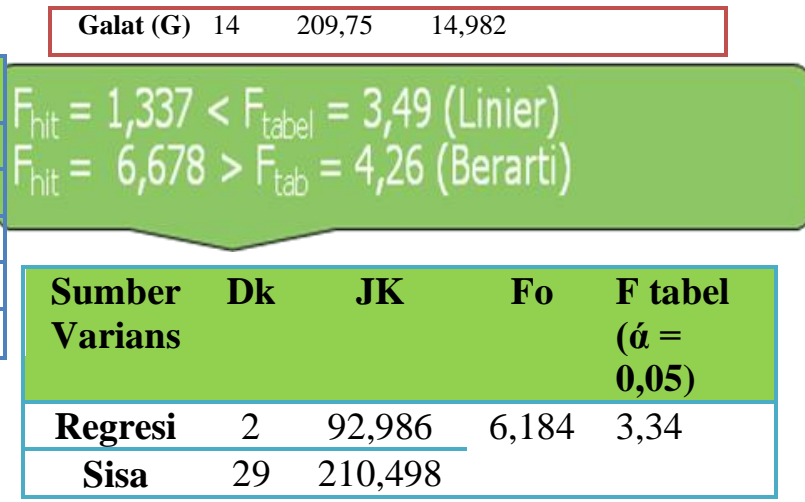

1. Korelasi Antar Variabel Korelasi Koefisien korelasi ( $\mathbf{N} \quad$ Harga t ( dk = 29, $=31, \alpha=0,05) \quad \alpha=0,05)$

1. Uji Normalitas

\begin{tabular}{|llll|} 
Variabel peneliti & dk & $\boldsymbol{\chi}^{\mathbf{2}}$ hitung & $\begin{array}{l}\boldsymbol{\chi}^{\mathbf{2}} \text { tabel }( \\
\mathbf{5 \%}\end{array}$ \\
$\begin{array}{l}\text { Fasilitas Bengkel Bangunan } \\
\left(\mathbf{X}_{1}\right)\end{array}$ & 5 & 10,245 & 11,070 \\
\hline Minat Belajar $\left(\mathbf{X}_{2}\right)$ & 5 & 6,825 & 11,070 \\
\hline $\begin{array}{l}\text { Hasil belajar Praktek Batu } \\
(Y)\end{array}$ & 5 & 8,818 & 11,070 \\
\hline
\end{tabular}

2. Uji Linieritas $\mathrm{Y}$ atas $\mathrm{X}_{1}$

\begin{tabular}{|c|c|c|c|c|c|}
\hline $\begin{array}{l}\text { Sumber } \\
\text { varians }\end{array}$ & DK & JK & RJK & $\mathbf{F}_{\text {hitung }}$ & $\begin{array}{l}\mathbf{F}_{\text {tabel }}(\dot{\alpha} \\
=0,05)\end{array}$ \\
\hline Total & 31 & 12272 & & & \\
\hline $\begin{array}{l}\text { Regresi } \\
\text { (a) }\end{array}$ & 1 & 7808,516 & & \multirow[t]{3}{*}{4,96} & \multirow[t]{3}{*}{4,18} \\
\hline $\begin{array}{l}\text { Residu } \\
\text { (b/a) }\end{array}$ & 1 & 0,95 & 0,95 & & \\
\hline $\begin{array}{l}\text { Residu } \\
\text { (S) }\end{array}$ & 29 & 302,534 & 10,432 & & \\
\hline $\begin{array}{l}\text { Tuna } \\
\text { Cocok } \\
\text { (TC) }\end{array}$ & 18 & 135,657 & 70,537 & \multirow[t]{2}{*}{0,496} & \multirow[t]{2}{*}{2,37} \\
\hline $\begin{array}{l}\text { Galat } \\
\text { (G) }\end{array}$ & 11 & 167,17 & 15,197 & & \\
\hline
\end{tabular}

\begin{tabular}{|c|c|c|c|c|c|}
\hline $\begin{array}{l}\text { Sumber } \\
\text { varians }\end{array}$ & DK & JK & RJK & $\mathbf{F}_{\text {hitung }}$ & $\begin{array}{c}\mathbf{F}_{\text {tabel }} \\
(\alpha= \\
\mathbf{0 , 0 5})\end{array}$ \\
\hline Total & 31 & 8112 & & & \\
\hline $\begin{array}{l}\text { Regresi } \\
\text { (a) }\end{array}$ & 1 & 7808,516 & & & \\
\hline $\begin{array}{c}\text { Regresi } \\
\text { (b/a) }\end{array}$ & 1 & 35,772 & 35,772 & 4,346 & 4,18 \\
\hline Residu (s) & 29 & 267,712 & 8,231 & & \\
\hline $\begin{array}{c}\text { Tuna } \\
\text { cocok (TC }\end{array}$ & 15 & 57,962 & 3,864 & 0,258 & 2,26 \\
\hline
\end{tabular}

\section{Analisis Regresi Ganda}

\section{$F_{\text {hit }}=1,829<F_{\text {tabel }}=3,24$ (linier)}

$F_{\text {hit }}=7,095>F_{\text {tab }}=4,26$ (Berarti)

Motivasi Belajar : cenderung cukup, $\mathrm{t}_{\text {hitung }}=3,124>\mathrm{t}_{\text {tabel }}=1,71$, terdapat konstribusi yang positif dan berarti antara motivasi belajar terhadap hasil belajar PDTB.

Disiplin Belajar cenderung cukup, $t_{\text {hitung }}=3,231>t_{\text {tabel }}=1,71$, terdapat konstribusi yang positif dan berarti antara disiplin belajar terhadap hasil belajar PDTB.

PDTB cenderung cukup, thitung $=4,799>t_{\text {tabel }}=1,71$

$30,50 \%$ skor PDTB dapat dijelaskan secara bersama-sama oleh motivasi belajar dan disiplin belajar. Terdapat konstribusi yang positif dan berarti antara motivasi belajar dan disiplin belajar terhadap hasil belajar PDTB.

1) Dimpu Nababan, alumni Pendidikan Teknik Bangunan FT Unimed

2) Drs. Iskandar Tambunan, M.Pd. Dosen Jurusan Pendidikan Teknik Bangunan FT Unimed 
Hubungan Antara Fasilitas Bengkel Bangunan Dan Minat Belajar Siswa Dengan Hasil Belajar Praktek Batu Pada Siswa Kelas Xi Program Keahlian Konstruksi Batu Dan Beton Smk Negeri 2 Pematangsiantar

\section{Pembahasan}

1. Semakin tinggi motivasi belajar maka hasil belajar pengetahuan dasar teknik bangunan juga akan semakin tinggi.

2. Semakin baik disiplin belajar maka hasil belajar pengetahuan dasar teknik bangunan juga akan semakin tinggi.

3. Semakin tinggi motivasi belajar dan semakin baik disiplin belajar maka hasil belajar pengetahuan dasar teknik bangunan juga akan semakin tinggi.

Sesuai dengan hasil penelitian ini, maka hipotesis yang diajukan dapat diterima. Untuk mengetahui lebih lanjut faktor yang berhubungan dengan Motivasi Belajar dan Disiplin Belajar serta Hasil Belajar Pengetahuan Dasar Teknik Bangunan Hasil Belajar dari siswa kelas X Program Keahlian Teknik Gambar Bangunan SMK Negeri 1 Berastagi Tahun Pelajaran 2011/2012, perlu diadakan penelitian lebih lanjut.

\section{KESIMPULAN}

Berdasarkan hasil penelitian yang telah diuraikan pada Bab IV, maka dapat disimpulkan,

1. Terdapat konstribusi yang positif dan berarti antara motivasi belajar dengan hasil belajar pengetahuan dasar teknik bangunan pada siswa kelas X Program Keahlian Teknik Gambar Bangunan SMK Negeri 1 Berastagi Tahun Pelajaran 2011/2012

2. Terdapat konstribusi yang positif dan berarti antara disiplin belajar dengan hasil belajar pengetahuan dasar teknik bangunan pada siswa kelas X Program Keahlian Teknik Gambar Bangunan SMK Negeri 1 Berastagi Tahun Pelajaran 2011/2012

3. Terdapat konstribusi yang positif dan berarti secara bersama-sama antara motivasi belajar dan disiplin belajar dengan hasil belajar pengetahuan dasar teknik bangunan pada siswa kelas $\mathrm{X}$
Program Keahlian Teknik Gambar Bangunan SMK Negeri 1 Berastagi Tahun Pelajaran 2011/2012

4. Koefisien determinasi $\left(\mathrm{R}^{2}\right)$ sebesar 0,276 menunjukkan 26,7\% dari varians Hasil Belajar Pengetahuan Dasar Teknik Bangunan dapat dijelaskan variabel bebas. Dengan kata lain skor motivasi belajar dan disiplin belajar dapat menjelaskan skor hasil belajar Pengetahuan Dasar Teknik Bangunan. Sedangkan sisanya $73,3 \%$ belum dapat dijelaskan karena berasal dari variabelvariabel lainnya yang tidak diperhitungkan dalam penelitian ini.

\section{IMPLIKASI}

1. Dengan demikian hipotesis pertama yang diajukan, maka upaya untuk meningkatkan hasil belajar pengetahun dasar teknik bangunan dapat dilakukan dengan menciptakan maupun meningkatkan persepsi siswa yang positif tentang motivasi belajar

2. Dengan diterimanya hipotesis kedua yang diajukan, maka upaya untuk meningkatkan hasil belajar pengetahuan dasar teknik bangunan dapat dilakukan dengan meningkatkan disiplin belajar siswa. Semakin tinggi motivasi belajar dan semakin baik disiplin belajar maka hasil belajar pengetahuan dasar teknik bangunan hasil belajar

3. Dengan diterimanya hipotesis ketiga yang diajukan, maka upaya meningkatkan hasil belajar pengetahuan dasar teknik bangunan adalah dengan menciptakan dan mempertahankan persepsi siswa yang positif tentang motivasi belajar oleh guru dan meningkatkan disiplin belajar siswa

1) Dimpu Nababan, alumni Pendidikan Teknik Bangunan FT Unimed

2) Drs. Iskandar Tambunan, M.Pd. Dosen Jurusan Pendidikan Teknik Bangunan FT Unimed 
Hubungan Antara Fasilitas Bengkel Bangunan Dan Minat Belajar Siswa Dengan Hasil Belajar Praktek Batu Pada Siswa Kelas Xi Program Keahlian Konstruksi Batu Dan Beton Smk Negeri 2 Pematangsiantar

\section{SARAN}

1. Seluruh guru SMK maupun para pegawai SMK diharapkan senantiasa memberikan motivasi-motivasi belajar kepada siswa agar dapat meningkatkan kemampuan belajar, sehingga persepsi siswa tentang motivasi belajar akan semakin baik terhadap hasil belajar pengetahuan dasar teknik bangunan.

2. Seluruh guru SMK maupun para pegawai SMK dapat mengajak siswa untuk disiplin dalam belajar, dengan memberikan arahan-arahan dan dorongan-dorongan kepada siswa dalam belajar, sehingga disiplin belajar akan dapat meningkatkan hasil belajar pengetahuan dasar teknik bangunan.

3. Seluruh guru SMK maupun para pegawai SMK diharapkan memberikan solusi-solusi yang tepat yang dapat membantu siswa menumbuhkan motivasi serta menerapkan disiplin dalam kegiatan belajarnya baik di sekolah atapun diluar sekolah.

4. Perlu diadakan penelitian lebih lanjut tentang Kontribusi Antara Motivasi Belajar dan Hasil Belajar Terhadap Hasil Belajar Pengetahuan Dasar Teknik Bangunan (PDTB) guna memperluas penelitin ini.

5. Hendaknya perlu diadakan lagi penelitian terhadap hasil belajar Pengetahuan Dasar Teknik Bangunan untuk meningkatkan hasil belajar siswa melalui variabel-variabel lainnya.

\section{DAFTAR PUSTAKA}

Arikunto, Suharsimi (2005), Dasar-dasar Evaluasi Pendidikan, Yogyakarta : Bumi Aksara.

Arikunto, Suharsimi (2006), Dasar-dasar Evaluasi Pendidikan, Yogyakarta : Bumi Aksara.
Arikunto, Suharsimi (2007), Dasar-dasar Evaluasi Pendidikan, Yogyakarta : Bumi Aksara.
B. Hurlock, Elizabeth (2010), Perkembangan Anak, Jakarta : Erlangga

Milfayetty, Sri, dkk (2010), Psikologi Pendidikan. Medan : PPs Unimed

Sardiman A.M (2010), Interaksi dan Motivasi Belajar, Jakarta : Rineka Cipta

Simanjuntak, Elfrida (2009), Hubungan antara Motivasi Berpresetasi dan Disiplin Belajar dengan Hasil Belajar Menggambar Teknik Pada Siswa Kelas X Bidang Keahlian Teknik Gambar Bangunan di SMK Negeri 1 Percut Sei Tuan TA 2008/2009, Medan : Perpustakaan Unimed

Slameto (2010) Belajar dan Faktor-faktor yang Memperngaruhinya, Jakarta : Rineka Cipta

S, Suparman (2010), Gaya Mengajar yang Menyenangkan Siswa, Yogyakarta : Pinus Book Publisher

Sudjana (2002), Metoda Statistika, Bandung : Tarsito

Sudjana, Nana (2009), Penilaian Hasil Proses Belajar Mengajar, Bandung : PT Remaja Rosdakarya 